\author{
ANITA STEFAŃSKA \\ Uniwersytet im. Adama Mickiewicza \\ w Poznaniu \\ MARIAN MARCINKOWSKI \\ Państwowa Wyższa Szkoła Zawodowa \\ w Głogowie
}

\title{
PEDAGOGICZNE I SOCJOLOGICZNE SPOJRZENIE NA ZDROWIE I BEZPIECZEŃSTWO ZDROWOTNE POLAKÓW
}

\begin{abstract}
Stefańska Anita, Marcinkowski Marian, Pedagogiczne i socjologiczne spojrzenie na zdrowie i bezpieczeństwo zdrowotne Polaków [Pedagogical and Sociological View at Health and Health Safety of Poles]. Studia Edukacyjne nr 51, 2018, Poznań 2018, pp. 387-402. Adam Mickiewicz University Press. ISSN 1233-6688. DOI: 10.14746/se.2018.51.23
\end{abstract}

The societies of developed countries, including Poland, are characterized by the dissemination of manifestations of the consumer lifestyle, which leads to a systematic deterioration of health and quality of life. The health and health safety should be systematically monitored and given in-depth scientific analyses, also from the perspective of pedagogy and sociology. In the scientific discourse there are various issues concerning both health hazards (inter alia related to globalization changes and lifestyle) and health promotion (for example, shaping pro-health attitudes and dissemination of participation in physical culture). Promoting a healthy lifestyle must be accompanied by investments in the material cultural-educational and sports-recreational base as well as by educational influences shaping the necessary level of knowledge and skills in the field of health.

Key words: health, health safety, health culture, healthy promotion

\section{Wstęp}

Obecne dynamiczne przemiany w życiu jednostek i społeczeństwa (m.in. postęp technologiczny czy przemiany ustrojowe i społeczno-ekonomiczne) wywołują znaczne przesunięcia na skali wartości uznawanych i odczuwanych. Zagrożone, niestety, zostają także wartości podstawowe, w tym zdro- 
wie. Kwestia uznawania wartości prozdrowotnych, w tym wartości usytuowanych w sferze kultury fizycznej, nie stanowi raczej problemu, bowiem wartości te zdeterminowane są zarówno instynktem samozachowawczym, jak i oddziaływaniami środowiskowymi na jednostkę. Problematyczne jest jednak odczuwanie owych wartości, na co wpływa zarówno samoocena stanu zdrowia jednostki (dobre samopoczucie nie skłania do zbyt częstej czy bieżącej refleksji o zdrowiu), jak i praktyczne preferencje w realizacji wartości (obecnie dominują - co od wielu lat podkreśla się w literaturze przedmiotu - style życia zorientowane raczej na „mieć” niż na „być”). Cywilizacja współczesna uwalnia jednostkę od konieczności intensywnego wysiłku fizycznego i niesie ze sobą pokusy wypoczynku biernego. Ludzie mają coraz więcej wolnego czasu, lecz, niestety, ograniczają się zwykle do konsumpcji, rezygnując z własnej różnorodnej aktywności. Człowiek przestał więc właściwie reagować na biologiczne sygnały organizmu, czego zasadniczym przejawem stał się niedobór ruchu, który wespół z innymi negatywnymi czynnikami wywołuje wiele chorób cywilizacyjnych.

Problematyka poruszana w artykule koncentruje się wokół pedagogicznych i socjologicznych aspektów kształtowania postaw wobec zdrowia i promocji zdrowia. Podejmując tę problematykę, autorzy zdają sobie sprawę, że modyfikacja systemu wartości oraz zachowań $\mathrm{w}$ kierunku pożądanego, zdrowego stylu życia zależy wprawdzie od wielu czynników, ale decydujące znaczenie należy jednak przypisać przemianom dokonującym się w samym człowieku, przemianom będącym przede wszystkim wynikiem procesów wychowania i samowychowania. O efektywności tych procesów decyduje głównie zgodne współdziałanie wszystkich środowisk oddziałujących na dzieci i młodzież, albowiem ukształtowane $\mathrm{w}$ okresie dorastania systemy wartości, postawy i zachowania, również w sferze kultury zdrowotnej i fizycznej, mają dużą szansę nie tylko przetrwania, ale i rozwoju w późniejszych etapach życia jednostki.

\section{Zdrowie współczesnych Polaków i jego zagrożenia}

Wzrost ekonomiczny krajów rozwiniętych skutkuje wprawdzie podniesieniem poziomu życia społeczeństwa w skali globalnej, ale nie gwarantuje w sposób automatyczny jego odpowiedniej jakości. Często zdarza się nawet, że ów wzrost przyczynia się do degradacji człowieka, zubożenia jego rozwoju jako istoty cielesnej, społecznej i kulturowej. Współcześnie zapominamy zazwyczaj o głębokiej prawdzie, że inwestowanie w ludzi jest dużo ważniejsze niż inwestowanie w maszyny. W sposób szczególny wyraził to E. Fromm, stwierdzając, że 
im bardziej z pozoru szalony i zdehumanizowany staje się ten nasz świat, tym żywszą jednostki mogą odczuwać potrzebę, by być i pracować z mężczyznami i kobietami, z którymi dzielić będą wspólne ludzkie troski ${ }^{1}$.

Aby ukształtowały się te potrzeby, ludzie muszą uświadomić sobie braki w dziedzinie warunków życia i narastające zagrożenia. Dla ludzi, którzy uznali potrzebę zmiany swego sposobu życia, a zwłaszcza dostrzegają konieczność przeciwdziałania zagrożeniom cywilizacyjnym, nadzwyczaj istotnym problemem staje się między innymi promocja zdrowia.

Podejmowane $\mathrm{w}$ ostatnich latach próby zdefiniowania zdrowia zaowocowały wyróżnieniem między innymi takich jego atrybutów, które wskazywały na potrzebę ujmowania zdrowia jako:

- pierwszej ze wszystkich wolności,

- antytezy choroby,

- braku poczucia dyskomfortu psychofizycznego (bólu, cierpienia),

- stanu równowagi (homeostazy),

- funkcjonalnej zdolności (możliwości wypełniania wysoko cenionych społecznie ról i zadań),

- witalności (dobrej kondycji),

- dobrostanu lub dobrobytu, rozumianego jako zapewnienie dostępności systemu opieki i leczenia,

- zasobu życiowego (warunku i bazy dla normalnego, codziennego funkcjonowania),

- wstępnego warunku partycypacji społecznej i aktywności ekonomicznej,

- warunku wstępnego utrzymania systemu społecznego czy elementu porządku społecznego ${ }^{2}$.

Obecnie Polska przeżywa w sferze ochrony zdrowia - podobnie jak też $\mathrm{w}$ innych dziedzinach - kryzys wynikający $\mathrm{z}$ trudności w przeprowadzeniu reform i braku przyzwolenia społecznego na odejście od idei odpowiedzialności państwa za zdrowie obywateli. Powodów tych trudności należy upatrywać przede wszystkim w zmianie społecznej dokonującej się nie tylko w sferze ekonomicznej, ale wymagającej również konsekwentnego przeprowadzenia głębokich przeobrażeń świadomościowych. W zakresie ochrony zdrowia szczególne znaczenie ma jego promocja, ważnym elementem której jest upowszechnianie zdrowego stylu życia. Do najczęściej występujących zachowań zagrażających zdrowiu należą przede wszystkim:

- niska aktywność fizyczna,

- nieprawidłowości w odżywianiu,

${ }^{1}$ E. Fromm, Zerwać okowy iluzji, Poznań 2000, s. 30.

2 Z. Woźniak, W stronę zdrowia społeczności - socjologiczny kontekst nowej polityki zdrowotnej, Ruch Prawniczy, Ekonomiczny i Socjologiczny, 2004, 1, s. 162. 
- palenie tytoniu, nadmierne spożycie alkoholu (zwłaszcza napojów wysokoprocentowych),

- używanie substancji psychoaktywnych (innych niż alkohol i nikotyna).

Znajduje to swoje odzwierciedlenie $w$ analizach dotyczących kondycji zdrowotnej współczesnych Polaków $w^{3}$ Stan zdrowia ludności Polski w latach 2000. stopniowo poprawia się (chociaż wolniej, zwłaszcza w przypadku mężczyzn, niż w latach 90. XX w.), ale na tle ogółu krajów Unii Europejskiej sytuacja w tym zakresie nie jest zadowalająca. Długość życia mieszkańców naszego kraju jest krótsza niż przeciętna w krajach UE: mężczyzn o 4,8 lat, a kobiet - o 2,1 lat. Najmniej korzystnym środowiskiem zamieszkania w Polsce są najmniejsze miasta, natomiast przeciętnie najdłużej żyją mieszkańcy największych miast (z wyjątkiem Łodzi). Największym zagrożeniem życia są choroby układu krążenia (w 2010 r. stanowiły one przyczynę 46\% ogółu zgonów Polaków). Drugą co do częstości przyczynę zgonów w Polsce (24,5\% ogółu zgonów w 2010 r.) są nowotwory złośliwe. Trzecią grupę stanowią (niestety) przyczyny niedokładnie określone (tu przyczyna zgonu zawierała opis objawów, odwoływała się do nieprawidłowych wyników badań laboratoryjnych, była niedokładnie określona, lub wręcz nieznana, co wydaje się niekorzystnie świadczyć o poziomie polskiej służby zdrowia w zakresie jakości systemu orzekania o przyczynach zgonów). Warto zwrócić jeszcze uwagę na czwartą grupę przyczyn zgonów, to jest przyczyny zewnętrzne $(6,5 \%$ zgonów w 2010 r.), do których zalicza się między innymi wypadki komunikacyjne i samobójstwa.

Charakteryzując najistotniejsze czynniki ryzyka zdrowotnego w obecnej dekadzie, należy stwierdzić, że $\mathrm{e}^{4}$ :

- spożycie alkoholu w Polsce w ciągu roku wynosi 10,1 litra na osobę (powyżej 15. roku życia) i jest nieco niższe od średniej europejskiej (10,7 litra/ osobę). Struktura spożycia różni się jednak od przeciętnej europejskiej, bowiem Polacy piją więcej alkoholi mocnych i piwa, a mniej wina;

- papierosy pali (wg danych z 2009 roku) codziennie 33,5\% mężczyzn (19. miejsce wśród 27 krajów Unii Europejskiej) oraz 21,0\% kobiet (20. miejsce). W stosunku do roku 1996 nastąpił spadek odsetka palących wśród mężczyzn, natomiast wśród kobiet rozpowszechnienie palenia nie zmieniło się w stopniu znaczącym, a najwyższym odsetkiem palących, zarówno wśród mężczyzn, jak i wśród kobiet, charakteryzuje się grupa osób z wykształceniem zasadniczym zawodowym;

${ }^{3}$ Podstawowym źródłem przedstawionych danych jest raport pt. „Sytuacja zdrowotna ludności Polski i jej uwarunkowania" (pod red. B. Wojtyniaka, P. Goryńskiego i B. Moskalewicz), wydany przez Narodowy Instytut Zdrowia Publicznego - Państwowy Zakład Higieny, Warszawa 2012.

${ }^{4}$ Tamże. 
- zwiększa się liczba Polaków z nadwagą lub otyłością (61,4\% mężczyzn z nadwagą to w 2009 roku jeden z wyższych odsetków w krajach EU), przy czym problem ten narasta wśród młodzieży szkolnej;

- spożycie owoców w Polsce jest jednym z najniższych w krajach EU, a szczególnie niekorzystnie przedstawia się to wśród dzieci i młodzieży, zwłaszcza najstarszej (w 2010 roku codziennie spożywało owoce tylko 15\% chłopców i 20\% dziewcząt, uczniów szkół średnich);

- w Polsce stosunkowo bardzo niski odsetek (6\%) osób uprawia systematycznie ćwiczenia fizyczne; ogólnie pod względem form aktywności fizycznej sytuacja jest nieco korzystniejsza i zbliżona do średniej UE (podejmuje je 26\% dorosłych). Również ogół młodzieży nie wypełnia przewidzianych dla tego wieku norm aktywności, chociaż należy zauważyć, że wśród chłopców i najmłodszych dziewcząt sytuacja w ostatnich latach się poprawia.

W świetle powyższego, najważniejsze staje się poszukiwanie sposobów intensyfikowania aktywności ruchowej społeczeństwa, w tym zwłaszcza dzieci i młodzieży. Nie chodzi tu jednak tylko o stworzenie odpowiednich warunków tak zwanych obiektywnych, albowiem o powodzeniu wszelkich działań $w$ tej dziedzinie ostatecznie decyduje to, czy jednostka potrafi z tych waruków skorzystać. W opracowanym na przełomie XX i XXI wieków „Narodowym Programie Zdrowia" ${ }^{5}$ sformułowano "ambitny" cel strategiczny w zakresie poprawy zdrowia i związanej z nim jakości życia ludności, zakładając, że do roku 2005 różne formy aktywności fizycznej w czasie wolnym będą udziałem co najmniej 50\% dzieci i młodzieży oraz 30\% dorosłych. Osiągnięcie założonego celu miało być możliwe jednak tylko wówczas, kiedy w procesie edukacji zdrowotnej zaakcentuje się w sposób szczególny znaczenie aktywności ruchowej człowieka jako przejawu stylu życia związanego z systemem wartości, w którym zdrowie zajmuje pozycję nadrzędną. Czy cel ten udało się osiągnąć? Można domyślić się, że niestety nie. Jak zauważają autorzy kolejnego programu (na lata 2007-2015), należy w roku 2007 ponownie, wzorem poprzednich raportów, stwierdzić, że

Polskie społeczeństwo cechuje niska aktywność fizyczna. Można szacować, że zaledwie około $30 \%$ dzieci i młodzieży oraz 10\% dorosłych uprawia formy ruchu, których rodzaj i intensywność obciążeń wysiłkowych zaspokajają potrzeby fizjologiczne organizmu6.

Dane te potwierdza również badanie Eurobarometr z 2009 roku, zgodnie z którym

Polska należy do krajów o niskim odsetku osób regularnie ćwiczących - 6\%, natomiast pod względem innych form aktywności fizycznej (spacery, jazda na rowerze,

${ }^{5}$ Narodowy Program Zdrowia (1996-2005), Ministerstwo Zdrowia i Opieki Społecznej, Warszawa 1996.

${ }^{6}$ Narodowy Program Zdrowia na lata 2007-2015. Załącznik do Uchwały Nr 90/2007 Rady Ministrów z 15 maja 2007 r., s. 31. 
taniec, prace ogrodnicze itp.) sytuacja jest korzystniejsza i zbliżona do średniej UE - 26\%. (...) Jednocześnie aż 49\% Polaków nie uprawia sportu w ogóle, zaś 17\% nigdy nie podejmuje innych form rekreacji fizycznej. Młodzież w Polsce również nie osiąga rekomendowanego poziomu aktywności, tj. co najmniej 60 minut dziennie ćwiczeń o umiarkowanej lub wysokiej intensywności ${ }^{7}$.

Zaznacza się przy tym, że odsetek ćwiczących zmniejsza się z wiekiem, szczególnie wśród dziewcząt (w roku 2010 odpowiedni poziom aktywności zadeklarowało tylko 4\% dziewcząt w wieku 17-18 lat).

W omawianym, ostatnim programie nie powtarza się jednak jako oczekiwanych efektów celu operacyjnego (celu 4: Zwiększenie aktywności fizycznej ludności) wskaźników z roku 2005 („,ambitnych”, ale nie osiągniętych), lecz stawia się kolejne „ambitniejsze” cele, zgodnie z którymi oczekuje się osiągnięcia w roku 2015 zaangażowania „w różne formy aktywności ruchowej o określonej intensywności i częstotliwości w czasie wolnym, co najmniej 60\% dzieci i młodzieży oraz 35\% dorosłych" ${ }^{8}$. Nasuwa się zatem pytanie: czemu taki zabieg służy? Zwłaszcza że, według autorów tego programu, podstawową przyczyną istniejącego stanu rzeczy jest niska świadomość w zakresie potrzeb sportu i rekreacji, a zatem zmianę w tej dziedzinie mogą przynieść przede wszystkim programy uaktywniające społeczeństwo, promocja rekreacyjnej aktywności ruchowej oraz oddziaływanie na pozytywną ocenę walorów aktywności ruchowej’. Nie ulega wątpliwości, że działalność służąca zwiększeniu świadomości jest nader złożona i wszelkich korzystnych zmian należy oczekiwać raczej w dłuższej perspektywie (ale na pewno nie w ciągu dekady). W procesie uświadamiania należy zwracać uwagę nie tylko na fakt, że podejmowanie aktywności ruchowej pozwala na kształtowanie sprawności i wydolności fizycznej oraz zachowanie i potęgowanie potencjału zdrowotnego organizmu, ale także możliwość i konieczność zaspokajania (poprzez aktywność fizyczną) w szerokim zakresie innych potrzeb jednostki, w tym potrzeby bezpieczeństwa.

\section{Bezpieczeństwo zdrowotne w dyskursie naukowym i praktyce społecznej}

Aktywne uczestnictwo w kulturze fizycznej, będące przejawem prozdrowotnego stylu życia, może stanowić jedną z ważniejszych dróg pokonywania różnorodnych sytuacji kryzysowych, jakie coraz częściej doświadczają

7 Cyt. za: A. Poznańska, D. Rabczenko, B. Wojtyniak, Wybrane czynniki ryzyka zdrowotnego związane ze stykem życia, [w:] Sytuacja zdrowotna ludności Polski i jej uwarunkowania, red. B. Wojtyniak, P. Goryński, B. Moskalewicz, Warszawa 2012, s. 301.

8 Narodowy Program Zdrowia na lata 2007-2015, s. 31.

9 Tamże. 
jednostki i zbiorowości. Owe sytuacje kryzysowe często zagrażają zdrowiu czy nawet życiu, na co od wielu lat wskazują wyniki badań epidemiologicznych oraz apele przedstawicieli środowisk naukowych, nie tylko związanych $\mathrm{z}$ medycyną. Bezpieczeństwu zdrowotnemu służy niewątpliwie

upowszechnienie prozdrowotnych stylów życia w populacji osób zdrowych oraz redukcja występowania zachowań będących czynnikami ryzyka bądź wpływających na ich pojawianie się u osób chorych. (...) działania interwencyjne mające na celu zmianę behawioralnych czynników ryzyka chorób (...) powinny uwzględniać modyfikację wpływów środowiskowych, warunkujących w istocie tę zmianę ${ }^{10}$.

Należy przy tym zwrócić uwagę na fakt, że zgodnie z założeniami paradygmatu biomedycznego działania ukierunkowane na zmianę stylu życia zwykle ograniczają się do edukacyjnego wpływu na jednostki, z pomijaniem czy ograniczaniem oddziaływania na czynniki społeczne i ekonomiczne.

Ograniczenie powyższe uwarunkowane jest między innymi przyjmowaniem $\mathrm{w}$ ramach tego paradygmatu tak zwanej negatywnej definicji zdrowia. Definicja taka budowana jest na założeniu, że zdrowy jest człowiek, u którego

nie stwierdzono choroby lub innych zaburzeń w stanie zdrowia. W przypadku problemów zdrowotnych mających korzenie społeczne (...) powyższy sposób rozumienia zdrowia odwraca uwagę od konieczności traktowania zdrowia jako zasobu i nie sprzyja tym samym podejmowaniu w populacji ludzi zdrowych bardzo wczesnych działań zapobiegawczych o charakterze przyczynowym, tj. zorientowanych na środowiskowe determinanty behawioralnych czynników ryzyka ${ }^{11}$.

Konsekwencją takiego podejścia w traktowaniu zdrowia (przyjęcia jego negatywnej definicji) jest koncentracja na chorobach oraz innych zaburzeniach w stanie zdrowia, co zwykle przejawia się - zarówno na poziomie pojedynczego człowieka, jak i systemu ochrony zdrowia - postawą wyczekiwania. Postawę taką cechuje przede wszystkim to, że jako właściwe traktowane są działania naprawcze, które podejmuje się dopiero wówczas, kiedy pojawia się problem zdrowotny. Wskazane jest jednak odejście (odchodzenie) od opisanego biomedycznego paradygmatu zdrowia i wybór paradygmatu socjoekologicznego, jednak pod warunkiem, że jego założenia będą z kolei wykorzystywane nie tylko w odniesieniu do działań populacyjnych realizowanych $\mathrm{w}$ ramach zdrowia publicznego, ale także będą aplikowane $\mathrm{w}$ tych obszarach opieki zdrowotnej, które mają znaczenie dla kształtowania zdrowych stylów życia. Nie budzi wątpliwości, że współcześnie o poziomie bezpieczeństwa zdrowotnego decyduje współdziałanie wielu podmiotów w sferze dbałości

${ }^{10}$ Z. Słońska, Promocja zdrowia w chorobach układu krążenia, [w:] Zdrowie publiczne. Wybrane zagadnienia, t. I, red. J. Opolski, Warszawa 2011.

${ }^{11}$ Tamże. 
o zdrowie (w tym przede wszystkim jednostka/człowiek, pracownicy służby zdrowia, jej instytucje i szeroko rozumiane instytucje oddziaływań społeczno-edukacyjnych), z zaakcentowaniem w tym współdziałaniu stylu życia jako istotnego determinanta tego bezpieczeństwa.

Regularna i szczegółowa kontrola czynników ryzyka zdrowotnego stanowi doskonały przykład nie tylko refleksyjności wobec zewnętrznych czynników zagrożenia, ale i współdziałania systemów eksperckich oraz zachowań laików. Specjaliści dostarczają materiałów do analizy rozkładu owego ryzyka, a ogół populacji w znacznym stopniu uświadamia sobie treść i znaczenie wyników tej analizy. Ich odbiór wpływa na style życia w całej populacji, chociaż zmiany wzorów zachowań zależą zazwyczaj od przynależności klasowej, przy czym profesjonaliści i grupy wysoko wykształcone podejmują je chętniej. Często zdarza się jednak tak, że stanowisko ekspertów - które w gruncie rzeczy rzadko kiedy bywa jednolite - nagle ulega zmianie,

nawet jeżeli uprzednio postulowane zmiany w obrębie stylów życia zostały już poczynione. (...) palenie kiedyś było zalecane przez pewne środowisko ekspertów jako środek odprężający, a żeby mieć zdrowe ciało, należało jeść krwiste mięso, masło i śmietanę $e^{12}$.

Podejścia i terminy medyczne zmieniają się w miarę jak poszczególne teorie są poddawane rewizji i odrzucane, a dodatkowo sytuacje komplikuje fakt, że w obrębie profesji medycznej w każdej kwestii panuje znaczna, niekiedy radykalna rozbieżność zdań co do czynników ryzyka oraz etiologii głównych chorób zagrażających życiu. Dość naturalne zatem wydaje się, że w obliczu takiej złożoności niektóre osoby tracą zaufanie do specjalistów w zakresie medycyny i wykazują niechęć do modyfikacji stylu życia. Młoda osoba ciesząca się dobrym zdrowiem może mieć pełną świadomość ryzyka, jakie wynika z palenia nikotyny, ale będzie ewentualne negatywne konsekwencje tego nałogu odnosić raczej do czasu należącego w jej pojęciu do nieprawdopodobnie dalekiej przyszłości. W tej sytuacji tego typu zagrożenia zdrowia zupełnie "rozmywają się" i zazwyczaj nie są obecnie postrzegane jako zbyt realne.

Holistyczne podejście $\mathrm{w}$ traktowaniu problematyki zdrowia, $\mathrm{w}$ tym jego interpretowania i definiowania pociąga za sobą również konieczność adekwatnego ujmowania zagrożeń zdrowia. Uwzględniać zatem należy nie tylko tradycyjny czynnik, czyli choroby, w tym w szczególności współcześnie nasilające się choroby cywilizacyjne, ale i inne zagrożenia zdrowotne (środowiskowe i społeczne). $W$ tej sytuacji bezpieczeństwo zdrowotne można określić przede wszystkim jako „stan gwarantujący brak zagrożeń mogących

${ }_{12}$ A. Giddens, Nowoczesność $i$ tożsamość. "Ja" i społeczeństwo w epoce późnej nowoczesności, Warszawa 2001, s. 166. 
powodować pogorszenie się lub utratę zdrowia statystycznego obywatela"13. Poczucie bezpieczeństwa zdrowotnego ściśle wiążą się ze świadomością dostępności opieki zdrowotnej oraz możliwości korzystania z niej w zakresie zaspokajającym potrzeby zdrowotne. Nie chodzi tu jednak tylko o dostępność w ogóle, lecz raczej o sprawiedliwą dostępność, która z kolei jawi się jako najważniejszy problem występujący w obszarze polityki zdrowotnej. Dostępność opieki zdrowotnej traktowana jest jako obywatelskie prawo wynikające zazwyczaj z umowy ubezpieczeniowej lub też uprawnienie uzależnione od sytuacji (zwłaszcza majątkowej) korzystającego. Cechami takiej dostępności (jako kategorii technicznej) są przede wszystkim ${ }^{14}$ :

- osiągalność: relacja między wielkością i strukturą zasobów znajdujących się w dyspozycji systemu a wielkością i strukturą potrzeb zdrowotnych określonej populacji, liczbą pracowników medycznych i jednostek infrastruktury przypadających na określoną liczbę ludności danego obszaru;

- dostępność przestrzenna (geograficzna): relacja między przestrzenną dystrybucją zasobów a terytorialnym rozmieszczeniem osób, które mają korzystać ze świadczeń;

- dostępność organizacyjna: stopień dopasowania organizacyjnych warunków udostępniania świadczeń i praktycznych możliwości korzystania przez pacjentów ze stosowanych rozwiązań;

- dostępność kosztowa (ekonomiczna), która w skali makro dotyczy zasad przyznawania uprawnień do korzystania ze świadczeń, a na poziomie mikro jest to postrzegana przez pacjenta jego zdolność do poniesienia kosztu związanego z kontaktem;

- akceptowalność: relacja między oczekiwaniami pacjenta dotyczącymi technicznych, psychologicznych i kulturowych aspektów zaspokajania potrzeb a stopniem spełnienia tych oczekiwań w warunkach konkretnego kontaktu ze służbą zdrowia. Odnosi się to głównie do postrzeganego przez pacjentów poziomu wiedzy i fachowej biegłości lekarza oraz innych pracowników medycznych.

Poziom bezpieczeństwa zdrowotnego w Polsce przedstawiany jest zazwyczaj w sposób krytyczny, niekiedy nawet katastroficzny, chociaż w rzeczywistości mamy do czynienia raczej z permanentnym kryzysem. W rzetelnych analizach tego problemu wskazuje się przede wszystkim na funkcjonalną nierównowagę społeczną i materialną, silnie zależną od zmian w bliższym i dalszym otoczeniu systemu zdrowotnego, przejawiającą się głównie w nie-

13 A. Ameljańczyk, T. Ameljańczyk, System monitorowania bezpieczeństwa zdrowotnego w państwie i jego zagrożeń, Roczniki KAE, 2012, 25, s. 12.

14 J. Ruszkowski, Zwiększenie bezpieczeństwa zdrowotnego. Ekspertyza finansowana ze środków projektu nr POPT.03.04.00-00-019/07, w ramach Programu Operacyjnego Pomoc Techniczna 2007-2013, na zlecenie Ministerstwa Rozwoju Regionalnego, Warszawa 2009, s. 6-7. 
możności sprostania oczekiwaniom zarówno beneficjentów systemu zdrowotnego (populacji), jak i kadry sektora publicznego ochrony zdrowia, co ma to niewątpliwie swoje konkretne konsekwencje dla bezpieczeństwa zdrowotnego Polaków ${ }^{15}$. Potrzebny jest zatem dynamiczny model równoważenia systemu zdrowotnego, dla którego najważniejsze są - zdaniem J. Ruszkowskiego - następujące założenia:

- środki na zdrowie są zawsze ograniczone,

- popyt na świadczenia zdrowotne jest nieograniczony,

- równowagę funkcjonalną systemu zdrowotnego bezpośrednio kształtuje przede wszystkim jego równowaga społeczna zewnętrzna, wyrażana stopniem spełnienia przez system oczekiwań zdrowotnych obywateli (populacji ${ }^{16}$.

Z ostatniego założenia wynika konstatacja następująca: nie budzi wątpliwości, że zarówno z teoretycznego, jak i praktycznego punktu widzenia system zdrowotny pozostaje zawsze mniej lub bardziej niezrównoważony, zaś nierównowaga funkcjonalna należy do jego naturalnych właściwości.

Dość skomplikowane jest rzetelne zbadanie i ścisłe ustalenie potencjału zdrowotnego jednostek i społeczeństwa, a zwłaszcza określenie progu bezpieczeństwa zdrowotnego. Należy tu na pewno uwzględnić szereg elementów składowych oraz kontekstów, w tym demograficzny, zdrowotny sensu stricto, instytucjonalny, kulturowy i stratyfikacyjny (pozycje społeczne i statusy) oraz ekonomiczny. Jak słusznie zauważa Z. Woźniak,

W miarę wyczerpujący model wyznaczania obszarów granicznych bezpieczeństwa socjalno-zdrowotnego uwzględniać musi wieloczynnikową analizę wzajemnego warunkowania zdrowia oraz kompleksu cech i zjawisk współokreślających położenie człowieka i grup społecznych, do których jednostka przynależy ${ }^{17}$.

Model taki, bazujący na całościowej koncepcji zdrowia, musi zakładać określenie wskaźników mierzących całkowity dobrostan oraz to, co pozwala określić zdolność posiadania i osiągania założonych przez jednostkę i społeczeństwo celów, odpowiadania na osobiste potrzeby, a także radzenia sobie w codziennym życiu ${ }^{18}$.

\footnotetext{
15 Tamże.

16 Tamże, s. 3.

17 Z. Woźniak, W stronę zdrowia społeczności, s. 168.
}

18 Cytowany wyżej autor zwraca uwagę na to, że istotną rolę w badaniach socjomedycznych odegrało wprowadzenie do nich socjologicznego pojęcia analitycznego, jakim był (za T. Parsonsem): „funkcjonalny status oznaczający stopień, w jakim jednostka jest w stanie sprostać społecznym oczekiwaniom w kwestiach związanych z pełnieniem przypisanych jej ról społecznych i to bez ograniczeń fizycznych lub umysłowych". Status ten, obudowany wieloma wskaźnikami, obejmował trzy zasadnicze domeny: fizyczną, psychologiczną i społeczną. Tamże, s. 162-163. 
W odniesieniu do bezpieczeństwa zdrowotnego zbiorowości zakłada się, że zdrowa zbiorowość zachowuje zdolność do trwania i funkcjonowania, mimo zachodzących zmian w jej obrębie i poza nią. Zbiorowość taka ma zatem nie tylko możliwość wypełniania funkcji teraźniejszych, lecz także przygotowana jest do podejmowania nowych wyzwań, opierając się na posiadanych zasobach i kulturze zdrowotnej. Ma ona przede wszystkim zdolność i możliwości prokreacji, pielęgnacji i opieki oraz wychowania nowych pokoleń, a gwarantuje jej to wypadkowa następujących zasobów i potencjałów:

a) zasobów ludzkich (m.in. liczba, jakość i stan zdrowia członków), materialnych (dochody, zasobność społeczności, gospodarstw domowych i systemu rodzinnego), strukturalnych (typy rodzin i konfiguracje stosunków spolecznych w zbiorowościach), funkcjonalnych (statusy i role społeczne) oraz zdolności adaptacyjnych (wzory radzenia sobie w sytuacjach kryzysowych oraz odporność na kryzys itp.);

b) potencjałów leżących poza systemem grup pierwotnych $w$ postaci: zasięgu i sieci powiązań społecznych, zaplecza instytucjonalnego, systemu zabezpieczeń społecznych oraz innych systemów wsparcia społecznego i systemu sygnałowego umożliwiającego szybkie reagowanie zasobów pozarodzinnych ${ }^{19}$.

Współcześnie, o czym już wspominano, ważnym problemem jest pomiar zagrożeń zdrowia, które $w$ bezpośredni sposób determinują poziom bezpieczeństwa zdrowotnego. Najistotniejszą kwestią do rozstrzygnięcia pozostaje tu obiektywność takiego pomiaru i dlatego niekiedy proponuje się przyjęcie wartości „fizycznych" charakterystyk poszczególnych zagrożeń, a wśród charakterystyk mierzalnych świadczących o wielkości zagrożenia wymienia się między innymi takie, jak:

- wskaźnik zapadalności na określone choroby cywilizacyjne,

- liczba śmiertelnych wypadków komunikacyjnych (przy określonych założeniach),

- liczba kilometrów autostrad (przy określonych założeniach),

- średni czas dojazdu karetki ratowniczej,

- dostępność określonych usług medycznych,

- liczba wypadków w pracy,

- spożycie alkoholu na jednego obywatela ${ }^{20}$.

Wskaźnikami zagrożeń bezpieczeństwa zdrowotnego społeczeństwa mogą być między innymi: średni wiek obywatela, wskaźnik umieralności (liczba zgonów w skali roku do ogólnej liczby ludności), wskaźnik zapadalności na choroby cywilizacyjne, stosunek liczby obywateli zdolnych do pracy do ogólnej licz-

19 Tamże, s. 168.

${ }^{20}$ A. Ameljańczyk, T. Ameljańczyk, System monitorowania bezpieczeństwa zdrowotnego, s. 13. 
by ludności w wieku produkcyjnym, wielkość przyrostu naturalnego i średnia długość życia ${ }^{21}$. Te wskaźniki zagrożeń zdrowotnych powinny być podstawą do formułowania założeń polityki zdrowotnej, rozumianej jako

zorganizowane, celowe, kompleksowe i międzysektorowe działania władz publicznych oraz innych podmiotów, służące kształtowaniu, utrzymaniu, ochronie i poprawie zdrowia oraz sprawności ludzi, a także tworzeniu warunków zwiększających potencjał jednostkowy i zbiorowy oraz instytucjonalny, umożliwiający członkom populacji rozwój osobniczy, utrzymanie i/lub poprawę jakości życia oraz samodzielne i niezależne funkcjonowanie ${ }^{22}$.

Do priorytetów tak rozumianej polityki zdrowotnej należy zaliczyć przede wszystkim redukowanie lub też eliminowanie zagrożeń zdrowotnych i ich skutków oraz źródeł obniżenia poziomu bezpieczeństwa zdrowotnego. Obecnie potrzebna jest „nowa” polityka zdrowotna, zorientowana zarówno na jednostkę, jak i zbiorowości oraz ich otoczenie (środowisko i instytucje) wspierające zdrowie. Największe znaczenie w poprawie bezpieczeństwa zdrowotnego $w$ przyszłości będzie miała społeczna świadomość zagrożeń zdrowotnych i związana z tym odpowiedzialność jednostkowa i zbiorowa, tak skutecznie kształtowane we wszelkich formach promocji zdrowia i profilaktyki zdrowotnej. Tylko takie podejście do polityki zdrowotnej zdoła przeciwstawić się dominującym współcześnie procesom i zjawiskom, do których zaliczyć należy chociażby rosnące koszty nowych technologii i procedur medycznych, rosnący standard życia i oczekiwania poprawy jego jakości, nowe style pracy, żywienia i wypoczynku nieobojętne dla zdrowia oraz rozwój konsumeryzmu i utowarowienie zdrowia ${ }^{23}$.

Zdrowotne programy profilaktyczne realizowane w Polsce, niestety, nie zawsze są właściwie przygotowane i niekiedy zarzuca się im zbyt silną medykalizację. Jako przykład można podać programy zorientowane na wyłonienie grup wysokiego ryzyka, a konkretniej skrining cytologiczny. Okazuje się, że "ryzyko jest tu definiowane medycznie (np. wiek najczęstszej zachorowalności), a nie społecznie (pozycja społeczna, kultura medyczna)"24. Taka profesjonalna, wyłącznie medyczna argumentacja na rzecz realizacji tej profilaktyki dość często mija się ze sposobem interpretacji choroby i związanego z nią ryzyka w odczuciu kobiet. Powoduje to, że

znacznym kosztem osiąga się niewielkie korzyści populacyjne, zlokalizowane tylko $\mathrm{w}$ pewnych segmentach społeczeństwa. Strategie te, zakładające mobilizację indy-

${ }^{21}$ Tamże.

${ }^{22}$ Z. Woźniak, W stronę zdrowia społeczności, s. 181.

${ }^{23}$ Tamże, s. 179.

${ }^{24}$ A. Ostrowska, Profilaktyka zdrowotna: interpretacje, definicje sytuacji, racjonalności (Przypadek profilaktyki ginekologicznej kobiet), Studia Socjologiczne, 2011, 3, s. 92. 
widualnych (psychologicznych, materialnych) zasobów, sprzyjają generalnie tym, którzy mają więcej zasobów, a więc poszerzają zakres nierówności. Zarzuca się im też, że prowadzą do medykalizacji uprzednio zdrowych jednostek i nie prowadzą do oddziaływania na przyczyny zjawiska (a przyczyny z różną siłą oddziałują na różne segmenty struktury społecznej) ${ }^{25}$.

Potrzebna jest zatem weryfikacja programów profilaktycznych adresowanych do różnych kategorii potencjalnych klientów opieki zdrowotnej, uwzględniająca zarówno ideę równości społecznej (w kontekście dostępności usług medycznych), jak i holistyczne podejście do zdrowia i choroby.

Osoby zajmujące się działaniami zapobiegawczymi powinny mieć bogatą wiedzę o czynnikach wspierających ludzkie zdrowie i rozwój oraz być zdolne do identyfikacji czynników etiologicznych i środowiskowych, aby najlepiej inspirować młodych ludzi do wzbogacania wiedzy o zdrowym stylu życia, co $\mathrm{w}$ procesie wychowania wiąże się wprost $\mathrm{z}$ kształtowaniem ich charakteru. Wbudowanie w działalność dydaktyczną szkoły funkcji wspomagania zdrowia, to uruchomienie różnorodnych zajęć, a szczególnie profilaktycznych, nie tylko przyczyniających się do rozwijania osobistych i grupowych możliwości młodych osób w tym zakresie, ale uczących wykorzystywania własnych potencjałów dla skutecznego radzenia sobie z trudnościami życiowymi, by tym samym zapobiegać problemom zagrażającym ich zdrowiu w szeroko ujętym psychospołecznym kontekście ${ }^{26}$. We współczesnym świecie szczególnie młodzi ludzie odczuwają skutki na przykład tłumienia w sobie uczuć, a wszakże to człowiek spontaniczny jest postrzegany jako zdrowy. Skutki utraty spontaniczności oraz indywidualności opisuje Erich Fromm pisząc „rezygnacja ze spontaniczności i indywidualności prowadzi do zablokowania życia. Choć żywy biologicznie człowiek staje sie emocjonalnie i umysłowo martwym automatem" 27 .

\section{Zakończenie}

Nie ulega wątpliwości, że współczesna cywilizacja oddala człowieka od naturalnych warunków egzystencji, co w konsekwencji prowadzi do dysfunkcji psychicznych i systematycznego pogarszania zdrowia i jakości życia. $\mathrm{W}$ tej sytuacji decydujące znaczenie mają jednostkowe wybory zmieniające nieprawidłowe nawyki i upodobania, głównie w zakresie odżywiania, aktywności ruchowej i używek. Dbałość o zdrowie powinno być również punktem wyjścia do uporządkowania szerszego pola w psychospołecznej przestrzeni,

\footnotetext{
${ }^{25}$ Tamże.

${ }_{26}$ Por. Z.B. Gaś, Młodzieżowe programy wsparcia rówieśniczego, Warszawa 1999, s. 19.

${ }^{27}$ E. Fromm, Ucieczka od wolności, Warszawa 1993, s. 127.
} 
w której porusza się jednostka. W Polsce osiąganiu celów zdrowotnych musi służyć zarówno pokonywanie barier związanych ze zmianą ludzkich zachowań, jak i systematyczny monitoring stanu zdrowia ludności oraz stylów życia (na wzór np. Wielkiej Brytanii czy Finlandii). Przedsięwzięcia te stanowią podstawę do oceny sytuacji zdrowotnej i jej dynamiki, co z kolei determinuje skuteczność działań zapobiegawczych. Ogólna strategia i metodologia promocji zdrowia ukierunkowanej na style życia ma szczególne znaczenie w przełamywaniu dominującego jeszcze paradygmatu choroby i skupieniu uwagi na możliwościach adaptacyjnych człowieka.

Uznając za konieczne rozstrzygnięcie sytuacji współczesnego człowieka stającego wobec licznych zagrożeń zdrowia, zarówno w skali makro jak i mikro, zakładamy, że stosownych zmian należy dokonać przede wszystkim w sferze osobowościowego funkcjonowania jednostki. Wszelkie poważne próby zbudowania koncepcji teoretycznych i ich praktycznych rozwiązań $\mathrm{w}$ dziedzinie dbałości o zdrowie w ostatecznej instancji nie mogą abstrahować od aksjologicznych i społeczno-psychologicznych aspektów stylu życia. Kondycja zdrowotna jednostki i społeczeństwa stanowi jedną z ważniejszych miar poziomu rozwoju cywilizacyjnego, przy czym równie ważny jak obiektywne wskaźniki i miary stosowane przez naukę jest stosunek ludzi do własnego zdrowia oraz to, w jakim stopniu dbałość o nie stanowi element ich stylu życia. Nie budzi wątpliwości, że właśnie styl życia i zachowania zdrowotne należą do najważniejszych, poddających się kontroli i modyfikacji czynników związanych z szeroko rozumianym zdrowiem jednostki i społeczeństwa. Od najwcześniejszego dzieciństwa powinny być zatem kształtowane umiejętności i nawyki ruchowe oraz dbałość o higienę ciała i higieniczny tryb życia, co wiąże się $\mathrm{z}$ kształtowaniem potrzeb samorealizowania się $\mathrm{w}$ aktywnych formach wypoczynku.

Najskuteczniejszą drogą do zdrowego stylu życia, u podstaw którego znajduje się aktywność ruchowa, jest działalność edukacyjna, zwłaszcza $\mathrm{w}$ środowisku dzieci i młodzieży. Skutkiem działań edukacyjnych powinien być $\mathrm{z}$ jednej strony wzrost świadomości stanu zagrożeń dla zdrowia jednost$\mathrm{ki}$, a z drugiej ukształtowanie potrzeb, które umotywują jednostkę do działania aktywnego i twórczego w tym zakresie. Potrzeby te wpisują się $\mathrm{w}$ jednostkowy system wartości człowieka przesądzający o wyborze stylu życia. Najpierw potrzeby te muszą zrodzić się w świadomości jednostek, a potem każdy musi samodzielnie szukać możliwości ich realizacji w akceptowanym przez siebie i środowisko stylu życia. Wszystko to stanowi podstawę - łącznie z motywacją emocjonalną - do kształtowania postaw jednostki wobec własnego ciała, troski o jego higienę, zdrowie, sprawność i urodę. Dużo łatwiej kształtować te postawy i zapobiegać dewiacjom w tym zakresie wtedy, kiedy aktywne ruchowo formy spędzania wolnego czasu i wypoczynku 
staną się nierozerwalnym elementem stylu jednostki. Zdrowie jako wartość szczególnie cenna dla każdej jednostki wymaga twórczego potraktowania, adekwatnego nie tylko do zasobów czasowych i materialnych danej osoby, ale i wymagań zdrowotnych związanych na przykład z wiekiem, miejscem zamieszkania, czy specyfiką pracy zawodowej.

W sytuacji, kiedy każdy człowiek jest odpowiedzialny za kształt swojego życia, w tym za jego jakość i zdrowie, potrzebny jest nowy system kształcenia ogólnego służący efektywnej realizacji zachowań związanych z bezpieczeństwem zdrowotnym. Edukacja jest inwestycją w człowieka, a jej zasadniczym wynikiem ma być między innymi wzrost świadomości zagrożeń dla zdrowia każdej jednostki. Celem edukacji jest między innymi kształtowanie motywacji do działania aktywnego i twórczego, zgodnie z pożądanym systemem wartości, przesądzającym o wyborze zdrowego stylu życia.

Edukacja zdrowotna jest drogą do stylu życia, którego najistotniejszymi zewnętrznymi przejawami, obok aktywności ruchowej, są higieniczny tryb życia, prawidłowe odżywianie i unikanie używek. Zadaniem tej edukacji jest kształtowanie systemu wartości i ukierunkowanie procesu rodzenia się potrzeb związanych z realizacją zdrowego stylu życia. Potrzeby te muszą najpierw zrodzić się $\mathrm{w}$ świadomości jednostek, a potem każdy musi szukać sam możliwości ich zaspokojenia $\mathrm{w}$ akceptowanym przez siebie i środowisko stylu życia. Wszystko to stanowi podstawę - łącznie z motywacją emocjonalną do kształtowania postaw jednostki wobec własnego ciała, troski o jego higienę, zdrowie, sprawność i urodę. Warto podkreślić przy tym, że dużo łatwiej kształtować te postawy i zapobiegać zjawiskom negatywnym w tym zakresie wtedy, kiedy aktywne ruchowo formy spędzania czasu wolnego i wypoczynku staną się nierozerwalnym elementem stylu życia jednostki.

Upowszechnianie zdrowego, aktywnego ruchowo stylu życia dorastających pokoleń wiąże się przede wszystkim z koniecznością przewartościowań w sferze wychowania w kulturze fizycznej i wychowania do czasu wolnego. Obie sfery wychowania powinny być ściśle związane z procesem wychowania zdrowotnego i promocji zdrowia. Ta ostatnia jest procesem ciągłym, wieloletnim, który ma doprowadzić w skali masowej do przekształceń indywidualnych stylów życia tak, by sprzyjały umacnianiu i rozwojowi potencjału zdrowotnego społeczeństwa. Osiągnięcie tego rodzaju przekształceń dokonuje się przez zmiany świadomości i zachowań zdrowotnych, do czego niezbędne są nie tyle działania o charakterze interwencyjnym, lecz wielopłaszczyznowe oddziaływanie podejmowane na różnych poziomach organizacji życia społecznego, skierowanych na jednostki, grupy i warunki ich życia. Jednym z elementów tego oddziaływania są systematycznie prowadzone badania naukowe $\mathrm{w}$ tej dziedzinie, a zwłaszcza upowszechnianie i praktyczne zastosowanie rezultatów tych badań. 


\section{BIBLIOGRAFIA}

Ameljańczyk A., Ameljańczyk T., System monitorowania bezpieczeństwa zdrowotnego w państwie i jego zagrożeń, Roczniki KAE, 2012, 25.

Fromm E., Zerwać okowy iluzji, Dom Wydawniczy „Rebis”, Poznań 2000.

Fromm E., Ucieczka od wolności, Warszawa 1993.

Gaś Z.B., Młodzieżowe programy wsparcia rówieśniczego, Wydawnictwo Śląsk, Warszawa 1999.

Giddens A., Nowoczesność i tożsamość. „Ja” i społeczeństwo w epoce późnej nowoczesności, Wydawnictwo Naukowe PWN, Warszawa 2001.

Lorenz K., Regres społeczeństwa, Państwowy Instytut Wydawniczy, Warszawa 1986.

Narodowy Program Zdrowia (1996-2005), Warszawa: Ministerstwo Zdrowia i Opieki Społecznej, 1996.

Narodowy Program Zdrowia na lata 2007-2015. Załącznik do Uchwały Nr 90/2007 Rady Ministrów z 15 maja 2007 roku.

Ostrowska A., Profilaktyka zdrowotna: interpretacje, definicje sytuacji, racjonalności (Przypadek profilaktyki ginekologicznej kobiet), Studia Socjologiczne, 2011, 3.

Poznańska A., Rabczenko D., Wojtyniak B., Wybrane czynniki ryzyka zdrowotnego zwiazane ze stylem życia, [w:] Sytuacja zdrowotna ludności Polski i jej uwarunkowania, red. B. Wojtyniak, P. Goryński, B. Moskalewicz, Narodowy Instytut Zdrowia Publicznego - Państwowy Zakład Higieny, Warszawa 2012.

Ruszkowski J., Zwiększenie bezpieczeństwa zdrowotnego. Ekspertyza finansowana ze środków projektu nr POPT.03.04.00-00-019/07, w ramach Programu Operacyjnego Pomoc Techniczna 2007-2013, na zlecenie Ministerstwa Rozwoju Regionalnego, Warszawa 2009.

Słońska Z., Promocja zdrowia w chorobach układu krążenia, [w:] Zdrowie Publiczne. Wybrane zagadnienia, t. I, red. J. Opolski, Szkoła Zdrowia Publicznego CMKP w Warszawie, Warszawa 2011.

Woźniak Z., W stronę zdrowia społeczności - socjologiczny kontekst nowej polityki zdrowotnej, Ruch Prawniczy, Ekonomiczny i Socjologiczny, 2004, 1. 